S2-12培養細胞系からの薬物代謝酵素誘導の定量的予測法の検討

\author{
○菊池高光、鷹橋俊之、長坂泰久、奥平和穂、林 正弘 \\ 東京理科大学薬学部 薬剤学研究室
}

\title{
QUANTITATIVE PREDICTION OF PHENOBARBITAL INDUCTION OF CYP2B IN VIVO FROM CULTURED HEPATOCYTES STUDIES
}

Takamitsu Kikuchi, Toshiyuki Takanohashi, Yasuhisa Nagasaka, Kazuho Okudaira and Masahiro Hayashi

Department of Pharmaceutics, Faculty of Pharmaceutical Sciences, Science University of Tokyo

【目的】薬物代謝酵素は薬物投与等により誘導 され、併用薬物やその薬物自体の体内動態を変化 させ、予想し得なかった副作用の発現や薬効の低 下を引き起こす。この薬物代謝酵素誘導の IN VITRO スクリーニング系として培養肝細胞が期 待されている。IN VITRO 代謝実験による薬物相 互作用の予測に関しては、酵素阻害に基づくもの については成功例が多数報告されているのに対し て、酵素誘導に関する相互作用については定量的 な予測の試みは少ない。今回、我々はモデル薬物 としてフェノバルビタール (PB) を用い、ラット における CYP2B の誘導効果を IN VITRO、IN VIVO 両系で比較し、定量的予測の可能性について検討 した(1)。

【実験法および解析法】IN VITRO 害験法:Wistar 系雄性ラット（150～200g）より、Collagenase 灌流 法により分離肝細胞 (肝実質細胞) を採取し、牛 血清（10\%）を含んだ Williams'E 培地で培養を行 い、4 時間後血清を含まない培地に交換し、培養 肝細胞サンプルを調製した。その後 PBを 3 $100 \mu \mathrm{M}$ の濃度で添加し、一定時間後誘導効果を測 定した。誘導効果は CYP2B 活性の指標となる Pentoxyresorufin の O-脱 pentyl 化 (PROD) 活性に より測定した。
IN VIVO 害験法 : Wistar 系雄性ラット $(150 \sim 200 \mathrm{~g})$ に 5 50mg/ $\mathrm{kg}$ の投与量で PBを腹腔内に単回およ び 1 日 1 回最大 3 日間繰り返し投与を行い最終投 与 24 時間後に肝臓を摘出、ミクロソームを調製し IN VITRO と同様にPROD 活性を測定した。

IN VITRO-IN VIVO の比較 : ラットにPBを腹腔内 に投与した時に得られた血漿中濃度推移より AUCを算出、投与期間で除し、血漿中非結合率を かけることにより平均血漿中非結合型濃度とし、 IN VITRO 実験の培地中濃度と対応させ、両系にお ける誘導効果を単回および繰り返し投与について 比較した。

【結果と考察】IN VITRO におけるPBによる CYP2B 誘導 : まず、誘導を開始する時期を肝細 胞接着時点と単層形成以降の時期に設定し、比較 を行った。肝細胞接着時点では肝細胞分散時の傷 害のためPBに対する反応性が低下していたが、培 養1日後ではPBに対する反応性は十分に回復して いた。CYP2B の誘導は PB 濃度依存性であり、そ の $\mathrm{EC} 50$ 值は $15 \mu \mathrm{M}$ 程度、誘導が最大に達する濃度 は $33 \mu \mathrm{M}$ 付近という結果が得られた。この結果は Nims らの報告とほぼ一致した ${ }^{(2)}$ 。また培養期間 を延長していくと PB を添加したものは PROD 活 性が上昇していくが、PB 非添加のものはその活性 
が低下していった。これは培養に伴う CYP の減少 によるものであると考えられている。この現象を 考慮に入れるため、誘導効果は PROD 活性の control との比で評価した。

IN VIVOでのPBによるCYP2B 誘導 : 誘導効果は 単回投与では投与量 5 50mg/kg の範囲で投与量 依存的に増加した。また繰り返し投与により誘導 効果は増大し、 $25 \mathrm{mg} / \mathrm{kg}$ の投与量で最大に達し、 その值は control の約 35 倍であった。これらのこと より誘導効果は投与量にのみ依存するのではなく、 投与回数の増加とともに上昇することが示された。 IN VITRO-IN VIVO の比較 : 単回投与については PB 濃度で normalize した場合、図に示すように、 最大值は IN VITRO、IN VIVO ともほぼ6倍と良い 対応がみられ、EC50 值についても IN VITRO、IN

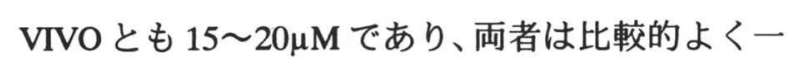
致した。また、繰り返し投与においても、同様に IN VITRO とIN VIVOの間には良い相関が得られた。
【結論】本研究の結果は、適切な評価法を用いれ ば、培養肝細胞系が IN VIVOにおける酵素誘導の 定量的予測のための IN VITRO 実験系となりうる ことを示している。

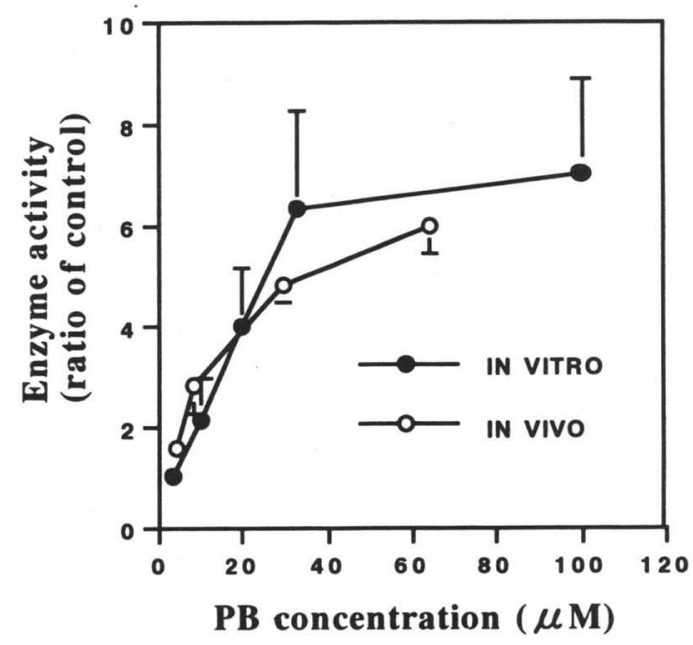

Comparison between in vivo and in vitro induction of CYP2B $24 \mathrm{hr}$ after single administration of PB.

\section{【ABSTRACT】}

In vitro-in vivo scaling works well for metabolic enzyme inhibition, but is less successful with enzyme induction. In this paper, we are attempt to establish the prediction method for enzyme induction in vivo from cultured hepatocytes studies. Phenobarbital (PB) was used as a model inducer for CYP2B and the enzyme activities were assessed by pentoxyresorufin O-depentylation (PROD). In vivo induction was determined in liver microsomes isolated from rats after administration of PB. In vitro induction was assessed in cultured rat hepatocytes treated with $\mathrm{PB}$. To compare in vitro induction with in vivo induction, plasma unbound concentration of $\mathrm{PB}$ has been used as a method of approximating unbound hepatocellular PB concentration in rats. Maximum induction (6 fold) and EC50 values $(15-20 \mu \mathrm{M})$ after single administration of PB were well agreed between in vitro and in vivo studies. Similar results were obtained in repeated administration of PB. In conclusion, although there still remain some problems for quantitative prediction of the enzyme induction, we showed the possibility and effectiveness of the prediction of inducibility in vivo from cultured hepatocytes.

\section{【REFERENCES】}

（1）菊池高光ら、日本薬学会第 117 年会講演要旨集 4、p6 （1997）

(2) R. W. Nims et al., Chem. Res. Toxicol. 6, 188-196（1993） 